\title{
Immune Response in COVID-19: Sero-Diagnostic Evidence for Clinical use and Research
}

\author{
Khan $\mathrm{SH}^{1 *}$, Zaidi $\mathrm{SK}^{2}$ \\ ${ }^{1}$ Department of Pathology, PNS HAFEEZ Hospital, Pakistan \\ ${ }^{2}$ Clinical Virologist \& Associate Professor of Pathology, Karachi Institute of Medical Sciences, Pakistan \\ *Corresponding author: Khan SH, Department of Pathology, PNS HAFEEZ Hospital, Pakistan. \\ To Cite This Article: Khan SH, Zaidi SK, Immune Response in COVID-19: Sero-Diagnostic Evidence for Clinical use and Research. 2020 - 11(1). \\ AJBSR.MS.ID.001585. DOI: 10.34297/AJBSR.2020.11.001585.
}

Received: 眥 November 18, 2020; Published: 眥 November 30, 2020

\begin{abstract}
Serological markers have remained the mainstay of infectious disease diagnosis and treatment monitoring for last so many decades. The comfort associated with serology testing has emerged from end user understanding, availability of "Rapid Point of Care testing (POCT)" formats and most importantly decreased turnaround times (TAT). In recent times, COVID-19 has burdened the healthcare systems across the globe. Rapid and accurate diagnosis is imperative to contain this contagion in the context of case detection, contact tracing, quarantine, admissions, therapeutic assessment for convalescent sera administration and epidemiological surveys for herd immunity. Nucleic Acid Tests (NAT) evolved as an accurate and early diagnostic modality and is currently considered as the standard in SARS-CoV-2 diagnosis. Though sensitive enough to pick up early disease, NAT testing is limited by false negative results in later half of the infection cycle along issues like higher cost, need for sophisticated equipment, skilled laboratory workers and oversight by pathologist thus hindering use on mass-scale. Serological diagnostic strategies, if used rationally may be a potentially cost-effective option for resource limited settings along with additional benefits for defining immune status and epidemiological surveys. This mini-review attempts to discuss and consolidate data on available and candidate serological markers including various antibodies (IgM, IgG and IgA), and antigen tests to guide clinical practitioners and researchers.
\end{abstract}

\section{Background}

The new normal for today is COVID-19; a reality with magnitudes of sorrow and losses and with humanity just taken aback despite the unmatchable list of scientific achievements and medical breakthroughs. It was in "Wuhan", the initial epicenter of this terrifying happening which further metamorphosed into a global pandemic. Puzzled with the extensive communicability and varying mortality of this virus, mankind also started to witness the socio-economic implications [1]. The disease "COVID-19" has undeniably emerged as the most discussed disease from the known times. Being new to mankind in many ways, certain characteristics of the disease need more research and science has yet to solve some basic queries for developing diagnostics and therapeutics.

An important caveat in diagnostic science remains the optimal and timely provision of results for managing care delivery pathways, which makes these test results central to the overall healthcare management. While Reverse Transcriptase- Polymerase Chain Reaction (RT-PCR) has a higher sensitivity and positive predictive value, key challenges include reliance on the time of testing during illness, higher cost, longer turnaround times (TAT) and need of skilled human resource [2]. In the wake of aforementioned limitations a window of need and opportunity arises where immune based diagnostics can fit in. We already appreciate the early derangements in terms of cellular immunity in patients with COVID-19 like leukopenia and lymphopenia [3]. Specific IgM and IgG immune responses have a time-tested evidence from multiple viral infections including dengue and hepatitis [4]. COVID-19 serological diagnosis is also available but current opinion about the use of IgM and IgG in the clinical setting is not well-established [5]. However, some researchers have shown some contrary evidence 
with more sensitivity and efficiency in diagnosing COVID-19 infections albeit in differing ways. Xie [6] and Li [7] have observed better performance of IgM-IgG combined kits than use of IgM alone in the diagnosis of COVID-19 [6,7]. The available COVID-19 serodiagnostics provide an argument based upon data variability, which varies between two extremes of opportunity in terms of a feasible conduct of reliable COVID-19 testing and inaccurate data leading to compromise in contact tracing. However, the authors are of the view that serological evidence provides us with opportunity for contact tracing and epidemiological studies apart from possible diagnostic utility in resource-limited medical facilities.

We therefore planned a review to analyze existing data on antibody and antigen testing for COVID-19. The objective was to provide an updated viewpoint on IgG, IgM and IgA antibody time kinetics and diagnostic performance along with evidence available on antigen tests for SARS-CoV-2.

\section{Review Methodology}

We used initially PubMed with search words "antibody tests in COVID 19". Further search was made on Google Scholars and Google in general to find more articles. We excluded following categories from our search: Articles not having free access $(n=12)$, case histories $(n=7)$, studies not dealing with diagnostic performance $(n=9)$, most commentaries and perspectives $(n=7)$, studies dealing solely with convalescent plasma $(n=5)$, studies dealing only with pathophysiology or for clinical usage $(n=19)$, studies dealing with antigen extraction methodologies and monoclonal Ab preparation $(n=16)$. We could only find many articles specifically dealing with the use of IgA in COVID-19 so we expanded a general search on Google to in- clude few more articles. Finally, data on using antigen was minimal and we attempted to incorporate some very preliminary diagnostic test evaluation data. The search was concluded in June-2020.

We shortlisted our research area into following categories to help address immune response and serological diagnosis in COVID-19 as: A- Time kinetics of SARS-CoV-2 antibodies, B-Diagnostic performance of IgM and IgG, C- Diagnostic performance of IgA antibody and D-Diagnostic performance of SARS-CoV-2 antigens

\section{Results}

We were able to consolidate data about various aspects of serological diagnosis in COVID-19. Firstly, the viral structure as depicted in Figure 1 guides us about the selection of various antigens and antibody response against these antigens. The interactions between different antigens and antibodies assessed through various techniques results in the response which is presented to clinics for interpretation. In any infectious disease various factors including time of testing during incubation period, underlying immune status and effect of associated disease like some autoimmune disorder finally determine the diagnosis potential of serological techniques. Therefore, we first attempted to evaluate the time kinetics of the antibodies with regards to infection onset and further course as presented in Table 1. Further on we discuss the diagnostic performance of IgM, IgG and IgA for diagnosing COVID-19 infection as shown in Table 2 and Table 3 respectively. Figure 2 shows the suggested pattern various serological markers along with viral RNA based upon our reviewed data.

Table 1: Literature review representing time kinetics and sero-conversion of antibodies after SARS-CoV-2 exposure.

\begin{tabular}{|c|c|c|c|c|c|c|}
\hline & Methods & $\mathbf{N}$ & Outcome measure & Diagnostic comment & Technical comment & Ref \\
\hline 1 & Chemiluminesence (ELISA) & $\mathrm{P}=173$ & $\begin{array}{l}\text { Sero-conversion \& } \\
\text { time kinetics for } \\
\text { SARS-CoV-2 }\end{array}$ & NA & $\begin{array}{c}\text { Combinations of RNA PCR with Abs, } \\
\text { IgM and IgG be used for diagnosis } \\
\text { Sero-conversion for Abs, IgM and IgG } \\
\text { was on day } 11,12,14\end{array}$ & [8] \\
\hline 2 & $\begin{array}{c}\text { ELISA (Gold } \\
\text { Immunochromatography (Innovi- } \\
\text { ta Co China) }\end{array}$ & $\begin{array}{l}\mathrm{P}=82 \\
\mathrm{C}=58\end{array}$ & $\begin{array}{l}\text { Time kinetics of IgM, } \\
\text { IgA \& IgG sero-con- } \\
\text { version }\end{array}$ & $\begin{array}{c}\text { Sensitivity } \\
(\mathrm{qPCR})=51.1 \% \\
\mathrm{qPCR}+\operatorname{IgM}=98.1 \%\end{array}$ & $\begin{array}{l}\text { Median IQR for IgM \& IgA appearance } \\
\text { was } 5 \mathrm{~d} \quad \text { Median IQR for IgG } \\
\text { appearance was 14d Combined use } \\
\text { of IgM \& qPCR suggested }\end{array}$ & [9] \\
\hline 3 & $\begin{array}{l}\text { Gold Immunochromatography } \\
\text { (Innovita Co China) }\end{array}$ & $\mathrm{P}=21$ & $\begin{array}{l}\text { Sero-conversion of } \\
\text { IgG \& IgM response } \\
\text { for S \& N protein }\end{array}$ & NA & $\begin{array}{l}\text { Ab sero-conversion predicts negative } \\
\text { results in NAT Sero-conversion } \\
\text { varied between less severe cases to } \\
\text { severe cases by } 10 \text { day to } 6 \text { weeks } \\
\text { Asymptomatic cases sometimes show } \\
\text { no sero-conversion Increase Ab titers } \\
\text { predicted severe disease }\end{array}$ & \\
\hline 4 & $\begin{array}{l}\text { Rapid method using “Colloidal } \\
\text { Gold Antibody Test (GICA)" for } \\
\text { IgM and IgG }\end{array}$ & $\mathrm{P}=38$ & $\begin{array}{l}\text { Comparison be- } \\
\text { tween RNA test \& } \mathrm{Ab} \\
\text { performance }\end{array}$ & $\begin{array}{l}\text { Overall sero-conversion } \\
\text { rate was } 50 \% \text { for IgM } \\
\text { and } 92 \% \text { for IgG }\end{array}$ & $\begin{array}{l}\text { Low positive rates for IgM ( } 23 \%) \\
\text { \& IgG(54\%) during early infection } \\
\text { IgM ( } 50 \%) \text { \& IgG ( } 88 \% \text { ) detection } \\
\text { improved over RNA testing from day- } \\
8 \text { of infection RNA test sensitivity was } \\
\text { lower in later half of disease (13\%) } \\
\text { than IgM ( } 52 \% \text { ) and IgG ( } 91 \%) \text { Com- } \\
\text { bined Ab+RNA testing suggested }\end{array}$ & [11] \\
\hline
\end{tabular}




\begin{tabular}{|c|c|c|c|c|c|c|}
\hline 5 & $\begin{array}{l}\text { Magnetic Chemiluminesce enzyme } \\
\text { assay [MGCLIA] }\end{array}$ & $\begin{array}{c}\mathrm{P}=285 \mathrm{FU} \\
\text { cohort } \\
(\mathrm{YCH})=63 \\
\text { FU of } 52 \\
\text { RT-PCR } \\
\text { neg }\end{array}$ & $\begin{array}{l}\text { Evaluating sero-con- } \\
\text { version \& IgM and } \\
\text { IgG sensitivity }\end{array}$ & $\begin{array}{l}\text { Overall Sensitivity for } \\
\qquad \operatorname{IgG}=83 \%\end{array}$ & $\begin{array}{l}\text { Median sero-conversion time was } \\
\text { 13d for both IgG and IgM, with incon- } \\
\text { sistent results for IgM Sero-conver- } \\
\text { sion of IgG with > } 4 \text { fold IgG increase } \\
\text { in sequential testing has diagnostic } \\
\text { sensitivity of 83\% Combined RT-PCR } \\
\text { with Ab testing approach recom- } \\
\text { mended }\end{array}$ & [12] \\
\hline 6 & $\begin{array}{c}\text { ELISA[(Livzon Diagnostics Inc.,) } \\
\text { Zhuhai, CHINA] }\end{array}$ & $\mathrm{P}=67$ & $\begin{array}{l}\text { Evaluation of host } \\
\text { serological and viral } \\
\text { time kinetics }\end{array}$ & $\begin{array}{l}\text { IgM rise }>\operatorname{IgG} \operatorname{IgG} \text { fall } \\
\text { later than IgM }\end{array}$ & $\begin{array}{l}\text { IgM rise by day } 10 \text { post infection and } \\
\text { decline by day } 30 \text { IgG start rising by } \\
\text { day } 20 \text { and remain elevated }\end{array}$ & [13] \\
\hline 7 & $\begin{array}{l}\text { A Cochrane review from } 54 \\
\text { studies }\end{array}$ & 16000 & $\begin{array}{l}\text { Week wise appear- } \\
\text { ance of Abs in SARS- } \\
\text { CoV-2 infection }\end{array}$ & $\begin{array}{l}\text { Week-1: } 30 \% \\
\text { Week-2: } 72 \% \\
\text { Week-3: } 94 \%\end{array}$ & $\begin{array}{l}\text { Correct testing timings have to be } \\
\text { used for better diagnostic yield }\end{array}$ & [14] \\
\hline
\end{tabular}

Table 2: Literature review showing diagnostic performance of IgM and IgG for SARS-CoV-2.

\begin{tabular}{|c|c|c|c|c|c|c|}
\hline & Methods & $\mathbf{N}$ & Outcome measure & Sensitivity/ Specificity & Technical comment & Ref \\
\hline 1 & Chemiluminesence & $\begin{array}{l}\mathrm{P}=43 \\
\mathrm{C}=33\end{array}$ & $\begin{array}{l}\text { Diagnostic perfor- } \\
\text { mance of IgM and IgG }\end{array}$ & $\begin{array}{c}\text { Sensitivity: } \operatorname{IgM}=48 \%, \operatorname{IgG}=89 \% \\
\text { and Specificity } \operatorname{IgM}=100 \%, \\
\operatorname{IgG}=91 \%\end{array}$ & IgG sensitivity > IgM & [15] \\
\hline 2 & ELISA & $P=3$ & $\begin{array}{l}\text { Evaluation of SARS- } \\
\text { CoV-2 IgA and IgG }\end{array}$ & $\begin{array}{l}\text { S1 specific IgG specificity more } \\
\text { than IgA }\end{array}$ & $\begin{array}{c}\text { Recommended IgG \& IgA } \\
\text { against S1-protein (SARS- } \\
\text { CoV-2) }\end{array}$ & [16] \\
\hline 3 & ELISA & $\begin{array}{l}P=66 \\
C=24\end{array}$ & $\begin{array}{l}\text { IgG/IgM performance } \\
\text { against } \mathrm{N} \text {-antigen }\end{array}$ & $\begin{array}{c}\text { Sensitivity, specificity, PPV, } \\
\text { NPV for IgM was } 77 \%, 100 \% \text {, } \\
\text { 100\%\&80\% while IgG was } 81 \% \text {, } \\
\text { 97\%, 85\% \& 89\%. specifici- } \\
\text { ty=97\% }\end{array}$ & $\begin{array}{l}\text { Sero-conversion by day } 4 \mathrm{Ab} \\
\text { provides help in diagnosis } \\
\text { Combined use of Ab test and } \\
\text { NAT recommended }\end{array}$ & [17] \\
\hline 4 & Lateral Flow Immunoassay & $\begin{array}{l}P=397 \\
C=128\end{array}$ & $\begin{array}{l}\text { Evaluation IgM-IgG } \\
\text { combined assay }\end{array}$ & Sensitivity $=87 \%$ Specificity $=91 \%$ & $\begin{array}{l}\text { Combined IgM/IgG provides } \\
\text { better sensitivity \& speci- } \\
\text { ficity }\end{array}$ & [18] \\
\hline 5 & $\begin{array}{l}\text { Rapid kits with different } \\
\text { methods }\end{array}$ & NA & $\begin{array}{l}\text { Meta-analysis com- } \\
\text { paring available tests }\end{array}$ & $\begin{array}{l}\text { 1-IgM sensitivity=82\% } 2 \text {-IgG sen- } \\
\text { sitivity }=97 \% \text { specificity }=98 \%\end{array}$ & $\begin{array}{l}\text { Antibody analysis help in } \\
\text { emergency setting IgM has } \\
\text { very low sensitivity in early } \\
\text { disease (10-44\%) }\end{array}$ & [19] \\
\hline 6 & CLIA (iFlash1800) & $\begin{array}{l}P=61 \\
C=64\end{array}$ & $\begin{array}{l}\text { Role of serologi- } \\
\text { cal diagnostics in } \\
\text { COVID-19 }\end{array}$ & $\begin{array}{l}\text { ROC analysis showed AUC } \\
\operatorname{IgM}=0.918 \mathrm{AUC} \operatorname{IgG}=0.980\end{array}$ & $\begin{array}{l}\text { Recommended using IgM/ } \\
\text { IgG for diagnosis }\end{array}$ & [20] \\
\hline 7 & $\begin{array}{l}\text { Comparison of different } \\
\text { methods }\end{array}$ & NA & Review & $\begin{array}{l}\text { IgM sensitivity (50-81\%), IgG } \\
\text { sensitivity }(81-100 \%)\end{array}$ & $\begin{array}{l}\text { Variables affecting Ab test } \\
\text { includes antigen selection, } \\
\text { cross-reactivity, test day } \\
\text { of incubation cycle and } \\
\text { patient's co-morbid }\end{array}$ & [21] \\
\hline 8 & ELISA & $\mathrm{P}=38$ & $\begin{array}{c}\text { Comparing IgM-IgG } \\
\text { with RT-PCR }\end{array}$ & NA & $\begin{array}{c}\text { Combined use of RT-PCR and } \\
\text { IgM-IgG is suggested }\end{array}$ & [22] \\
\hline 9 & $\begin{array}{c}\text { Rapid method [GCCOV } \\
\text {-402a, "Zhejiang Orient } \\
\text { Gene Biotech Co Ltd"(Chi- } \\
\text { na)] }\end{array}$ & $\begin{array}{l}P=29 \\
C=124\end{array}$ & $\begin{array}{c}\text { Evaluation of IgM-IgG } \\
\text { rapid method against } \\
\text { RT-PCR }\end{array}$ & $\begin{array}{c}\text { Sensitivity IgM }=69 \%, \operatorname{Ig} G= \\
93 \% \text { Specificity } \operatorname{IgM}=100 \%, \operatorname{IgG} \\
=99 \%\end{array}$ & $\begin{array}{l}\text { High negative predictive } \\
\text { value to rule out COVID-19 } \\
\text { Indicates past infection \& } \\
\text { possible immune status }\end{array}$ & [23] \\
\hline 9 & ELISA & $P=214$ & $\begin{array}{l}\text { Comparative assess- } \\
\text { ment of Abs to N and } \\
\text { S protein against NAT }\end{array}$ & $\begin{array}{c}\text { N-Protein sensitivity } \operatorname{IgM}=68 \% \text {, } \\
\operatorname{IgG}=70 \% \text { S-protein sensitivity } \\
\operatorname{IgM}=77 \%, \operatorname{IgG}=74 \%\end{array}$ & $\begin{array}{c}\text { Ab was less sensitive in } \\
\text { initial phase of disease but } \\
\text { increased in later half of } \\
\text { disease Supplementary use } \\
\text { advised }\end{array}$ & [24] \\
\hline
\end{tabular}




\begin{tabular}{|c|c|c|c|c|c|c|}
\hline 10 & $\begin{array}{l}\text { Colloidal Gold Labeled } \\
\text { Immuno Chromatography }\end{array}$ & NA & $\begin{array}{l}\text { Review of IgM \& IgG } \\
\text { diagnostic perfor- } \\
\text { mance }\end{array}$ & $\begin{array}{l}\text { Sensitivity: } \operatorname{Ig} M=73 \%, \operatorname{IgG}=100 \% \text {, } \\
\text { Specificity: } \operatorname{Ig} M=99 \%, \operatorname{IgG}=100 \%\end{array}$ & $\begin{array}{l}\text { More data needed to authen- } \\
\text { ticate due to variability in } \\
\text { findings }\end{array}$ & [25] \\
\hline 11 & Review of 53 studies & - & $\begin{array}{l}\text { Evaluation of sensi- } \\
\text { tivity \& specificity }\end{array}$ & Varying results & $\begin{array}{l}\text { Only combined use of anti- } \\
\text { body testing and RT-PCR was } \\
\text { suggested }\end{array}$ & [26] \\
\hline 12 & $\begin{array}{c}\text { Comparison of LFIA, ELISA } \\
\text { and CLIA }\end{array}$ & 293 & $\begin{array}{l}\text { Comparison of given } \\
\text { methods with RT-PCR } \\
\text { results }\end{array}$ & $\begin{array}{l}\text { All method's sensitivity }=100 \% \\
\text { IgG specificity with LFIA and } \\
\text { CLIA >ELISA }\end{array}$ & $\begin{array}{l}\text { Sensitivity by all three meth- } \\
\text { ods was } 100 \% \text { LFIA \& CLIA } \\
\text { are more specific than ELISA }\end{array}$ & [27] \\
\hline
\end{tabular}

Table 3: Reviewed data on SARS-CoV-2 IgA as serological biomarker.

\begin{tabular}{|c|c|c|c|c|c|c|}
\hline & Methods & $\mathbf{N}$ & Outcome measure & Sensitivity/ Specificity & Advantages & Ref \\
\hline 1 & ELISA & $\begin{array}{l}\mathrm{P}=82 \\
\mathrm{C}=58\end{array}$ & $\begin{array}{l}\text { Time kinetics of IgM, } \\
\text { IgA \& IgG sero-con- } \\
\text { version }\end{array}$ & $\begin{array}{c}\text { Sensitivity }(\mathrm{qPCR})= \\
\begin{array}{c}51.1 \% \mathrm{qPCR}+\mathrm{IgM}=98.1 \% \mathrm{qPCR} \\
+\operatorname{IgM}=98.1 \%\end{array}\end{array}$ & $\begin{array}{l}\text { Median IQR for IgM \& IgA appearance was } \\
\text { 5d Median IQR for IgG appearance was 14d } \\
\text { Combined use of IgM \& qPCR suggested }\end{array}$ & [9] \\
\hline 2 & ELISA & NA & NA & NA (Full text NA) & $\begin{array}{l}\text { IgA spike appears earlier by } 4 \mathrm{~d} \text { than IgM } \\
\text { (6d) and remains higher, long-lasting and } \\
\text { has a persistent performance }\end{array}$ & {$[28]$} \\
\hline 3 & ELISA & NA & $\begin{array}{l}\text { Diagnostic evaluation } \\
\text { of SARS-CoV-2 anti- } \\
\text { gens, IgA and IgG }\end{array}$ & $\begin{array}{l}\text { S1 specific IgA demonstrated } \\
\text { higher sensitivity for SARS- } \\
\text { CoV-2 but S1 specific IgG } \\
\text { showed higher specificity than } \\
\text { IgA }\end{array}$ & $\begin{array}{c}\text { Recommended IgG \& IgA against S1 protein } \\
\text { of SARS-CoV-2 }\end{array}$ & [16] \\
\hline 4 & Review & NA & $\begin{array}{l}\text { Evaluation of natural } \\
\text { history of } \operatorname{IgA}, \operatorname{IgM} \\
\text { and } \operatorname{IgG}\end{array}$ & NA & $\begin{array}{c}\text { IgA show response in early phase followed } \\
\text { by IgM and mainly IgG in later half of } \\
\text { disease }\end{array}$ & [29] \\
\hline \multirow[t]{2}{*}{5} & $\begin{array}{l}\text { CLIA method for } \\
\text { measuring } \mathrm{N} \text {-antigen } \\
\text { and RBD }\end{array}$ & $\mathrm{P}=87$ & $\begin{array}{l}\text { Comparison between } \\
\text { N-antigen and } \\
\text { RBD-antigen based } \\
\text { Abs including IgA, IgM } \\
\text { and IgG }\end{array}$ & $\begin{array}{l}\text { Abs sensitivity against RBD } \\
\text { antigen were: } \operatorname{IgA}=98.6 \% \text {, } \\
\text { IgM=96.8\%, } \operatorname{IgG}=96.8 \%\end{array}$ & $\begin{array}{l}\text { Higher diagnostic performance with RBD } \\
\text { than } \mathrm{N} \text {-antigen }\end{array}$ & [30] \\
\hline & & $C=483$ & & $\begin{array}{l}\text { Abs specificity against RBD } \\
\text { antigen were: } \operatorname{IgA}=98.1 \% \text {, } \\
\operatorname{IgM}=92.3 \%, \operatorname{IgG}=99.8 \%\end{array}$ & $\begin{array}{l}\text { IgA adds to improve sensitivity \& early } \\
\text { detection IgA correlates with COVID-19 } \\
\text { severity }\end{array}$ & \\
\hline 6 & $\begin{array}{l}\text { Proteome-peptide } \\
\text { Microarrays for Abs } \\
\text { Flow cytometer for } \\
\text { B-cell derived cells }\end{array}$ & NA & $\begin{array}{l}\text { Comparative analysis } \\
\text { of V-derived cells and } \\
\text { Abs in COVID-19 }\end{array}$ & NA & $\begin{array}{c}\text { IgA showed early response As a prognostic } \\
\text { marker higher IgA levels are associated } \\
\text { with bad prognosis }\end{array}$ & [31] \\
\hline
\end{tabular}

Table 4: Review of data on SARS-CoV-2 infection diagnosis utilizing antigen test.

\begin{tabular}{|c|c|c|c|c|c|c|}
\hline & Methods & $\mathbf{N}$ & Outcome measure & Sensitivity/ Specificity & Advantages & Ref. \\
\hline 1 & $\begin{array}{l}\text { Field Effect Transistor } \\
\text { Biosensing Device }\end{array}$ & NA & $\begin{array}{l}\text { Detection of SARS-CoV-2 } \\
\text { in culture media }\end{array}$ & Limit of detection very low & $\begin{array}{l}\text { Need proof of concept evaluation } \\
\text { in real-time clinical practice }\end{array}$ & [36] \\
\hline 2 & ICT method & 328 & $\begin{array}{l}\text { Evaluation of N-antigen } \\
\text { detection against qRT- } \\
\text { PCR }\end{array}$ & $\begin{array}{l}\text { Sensitivity }=58 \% \\
\text { ity }=99.5 \% \\
83 \% \text { against a ct qRT-PCR threshold } \\
\text { of }<22\end{array}$ & $\begin{array}{l}\text { Promising results against conven- } \\
\text { tional gold standard qRT-PCR }\end{array}$ & [37] \\
\hline 3 & ICT method & 774 & $\begin{array}{l}\text { Antigen test evaluation } \\
\text { against qRT-PCR }\end{array}$ & $\begin{array}{c}\text { Median positive } \% \text { agreement }=24 \% \\
\text { with up to a very high false positive } \\
\text { rate }(76 \%)\end{array}$ & $\begin{array}{l}\text { The diagnostic performance of this } \\
\text { technique was demonstrated to be } \\
\text { poor even with a very low selected } \\
\text { ct values of qRT-PCR }\end{array}$ & {$[38]$} \\
\hline 4 & ICT method & 148 & $\begin{array}{l}\text { Evaluation of N-antigen } \\
\text { detection against qRT- } \\
\text { PCR }\end{array}$ & $\begin{array}{c}\text { Sensitivity }=30 \% \quad \text { Spec- } \\
\text { ificity }=100 \% \text { Overall accuracy = } \\
50 \% \text { against a ct threshold of qRT- } \\
\text { PCR of } 26\end{array}$ & $\begin{array}{l}\mathrm{N} \text {-antigen test for SARS-CoV-2 has } \\
\text { high NPV and specificity Not good } \\
\text { for screening }\end{array}$ & [39] \\
\hline
\end{tabular}




\begin{tabular}{|c|c|c|c|c|c|c|c|}
\hline 5 & ICT method & 127 & $\begin{array}{l}\text { Evaluation of } \mathrm{N} \text {-antigen } \\
\text { detection against qRT- } \\
\text { PCR }\end{array}$ & $\begin{array}{l}\text { Sensitivity = 94\% } \\
\text { ficity }=100 \% \\
=96 \& \quad \text { cient }=0\end{array}$ & $\begin{array}{r}\text { Speci- } \\
\text { Accuracy } \\
\text { Kappa co-effi- } \\
.9\end{array}$ & $\begin{array}{l}\text { The test has high sensitivity } \\
\text { and specificity Can be used for } \\
\text { screening }\end{array}$ & [40] \\
\hline
\end{tabular}

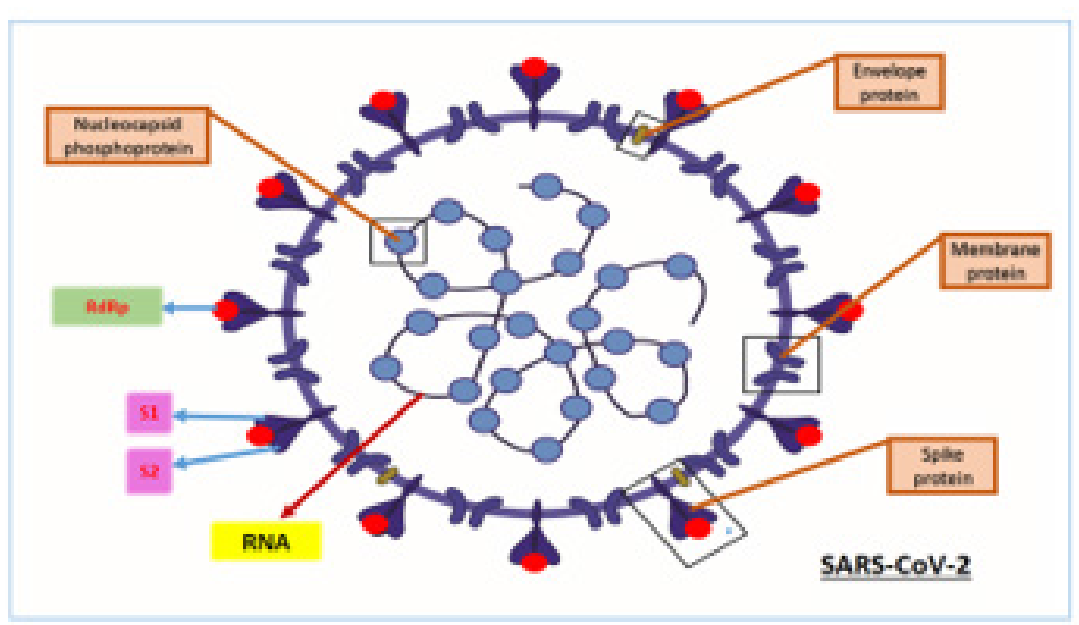

Figure 1: Schematic showing SARS-CoV-2 virus with various protein and RNA.

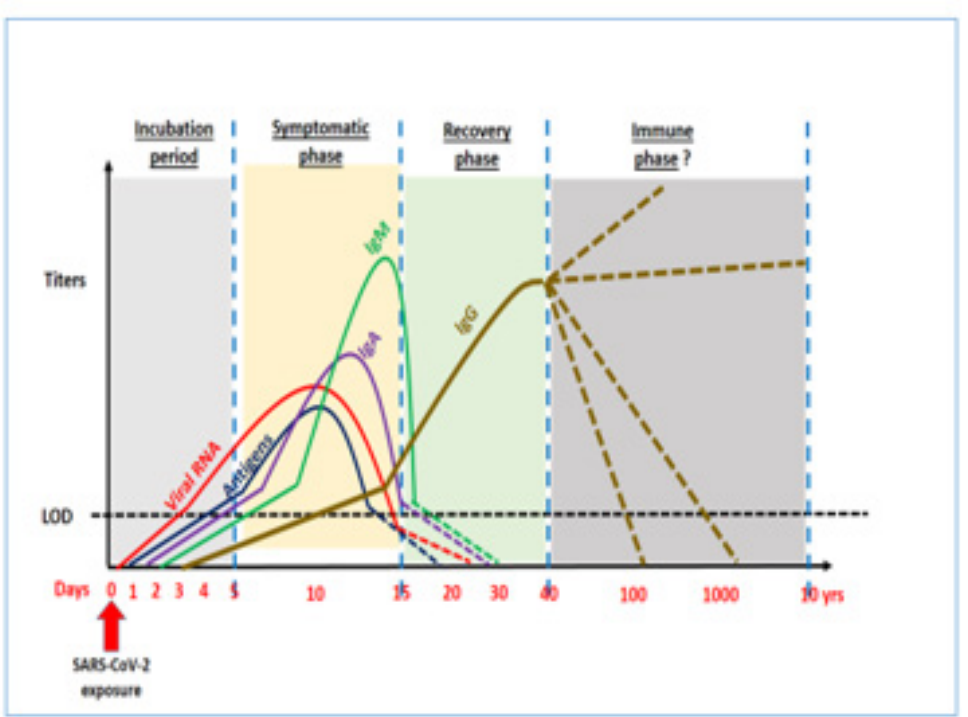

Figure 2: Schematic showing Time kinetics of COVID-19 and rise and fall of Antigens, viral loads, various antibodies.

Another rapid testing methodology on the horizon is SARSCoV-2 antigen detection. Currently, not much data exists with regards to availability and most importantly performance evaluation of antigen detection for this virus. However, the concept has been validated in the past for other viruses like Dengue by immunoassay for "Dengue NS-1 antigen" and SARS-CoV [32,33]. In lieu past research, the clinical market is taking on the flight to develop antigenbased assays. The usual targets considered for antigens include detection include S1, S2, Whole spike, Nucleocapsid, S1 STD and S1 RBD [34]. The assumed benefit of using COVID-19 antigen tests remains in the increased sensitivity to detect the infection without any need for the requirement of highly sophisticated instruments, skilled expertise and cost [35]. The antigen test though promising has limited data to support as shown in Table 4. While the PCR technique has limitations as explained above and diagnostic Antibody testing may not be useful for early detection, antigen detection may be a possibility in our fight towards early detection of COVID-19 especially at primary care medical set up and more so in community and resource limited settings. 


\section{Discussion}

Though we are in the initial phase of COVID -19 sero-diagnosis, the authors believe the need of the hour is to develop validated immunologic assays not only for COVID-19 case identification but also for contact tracing, epidemiological evaluation of immunity and probable utility in therapeutic slogan associated with convalescent sera donations. In the long-term disease management utilizing serological testing will probably be need more often. The specific Abtests for COVID-19 are currently focused towards Spike protein or its sub-units and nucleocapsid with an earliest detectable rise after 5-8 days (IgM) /5-15 days ( $\operatorname{IgG}$ ) with maximum titers around 10-20 days (IgM) /10-30 days (IgG) and troughs reaching around 20-30 days (IgM) with less clarity on IgG with enormous data variability [8-12]. However, most studies in this regard show a consensus that $\mathrm{Ab}$-test including IgM may not have the requisite diagnostic sensitivity in the earliest phase of COVID-19 diagnosis [8,9,11,13]. Studies designed to assess the diagnostic performance show variable data, which probably resulted due to factors inherent to antibody targets, incubation time-frame of testing, cross-reactants and patient symptomatology. Our reviewed data, still suggests a very high diagnostic sensitivity and specificity for IgG in comparison to IgM which could be related to the timings of analysis during COVID 19 infection [15-27]. However, multiple authors have suggested to combine the use of IgM, IgG and NAT test to gain higher diagnostic efficiency $[17,20,24,18]$. Another important aspect related to above discussion is the fact that almost all studies have demonstrated low sensitivity for IgM in earlier disease phase ranging as low as $48 \%$ to highest being $82 \%[15,19]$.

Another aspect worth appreciating is minimal focus on IgA antibody which is notoriously high in secretions including nasopharyngeal specimens in respiratory tract infections. We reviewed this area and found IgA to be sensitive in the early phase of the disease from $4 \mathrm{~d}$ to $6 \mathrm{~d}$ which closely overlaps with the timeframe of PCR positivity [2,9,29-31]. The sensitivity seems to increase by more than $98 \%$ by using IgA against the RPD antigen than N-antigen as demonstrated by Ma [16,30]. We as authors feel IgA being secretory antibody in respiratory epithelia could be an ideal serological biomarker marker for detecting early disease. More quality trials are warranted to tap its complete potential as early disease biomarker.

Antigen testing is one more area where early detection of disease is possible as has been employed in various infectious threats including the previous SARS-CoV outbreak [32-33]. Recently the research though preliminary and to some extent contrasting with our hopes, still allowed some valuable data on use of candidate antigens on spike and nucleocapsid proteins [34-40]. We feel that assessing antigen rather than antibody can provide higher diagnostic sensitivity for early detection in coming days.
Certain limitations to this review need to be emphasized: COVID-19 is a rapidly evolving healthcare research theme and ongoing research may provide better insight to various aspects of serological diagnostics. Secondly, the authors feel that most authors cited in this research have shared their shortcomings, which may be taken into considerations while deciphering clinical applications. Thirdly, some research work still needs to publicized and final shape of preprints may emerge differently. Lastly, the data related to COVID-19 is increasing by every day and every research suffers with the half-life issue. The current data only attempts to consolidate data as per the submission dates.

Amidst research limitations, rapidly growing data on the subject and expanding bio-technological innovations the study has been able to define some unchartered domains revolving serology diagnostic areas in a consolidated manner for future users. More significant to highlight here is the pivotal work pertaining to the use of IgA antibodies and potential of SARS-CoV-2 associated antigens in research, which may revolutionize in futuristic "plug and play" diagnostics at the bed site. We also feel the feasibility of serological COVID-19 diagnostics will finally lead the main battle front in fight against the pandemic by providing timely diagnostics, ruling out disease in NAT negative suspects, defining the end of active disease by PCR negativity and disappearance of IgM antibody, appearance of protective IgG and/or neutralizing antibody, measuring herd immunity in community and finally paving way for possible convalescent sera use in COVID-19 therapeutics by deploying IgG titers and neutralizing antibodies.

\section{Conclusion}

IgM and IgG are not useful in isolation to provide early diagnosis during COVID-19 infection. However, both can have a role in supplementing PCR test results for diagnosing COVID-19. IgG as a marker of past infection along with neutralizing antibodies can help in defining immunity from SARS-CoV-2 infection, measuring herd immunity status and therapeutic use in assessing compatibility for convalescent sera. IgA has the potential to develop as an early disease marker along with various candidate SARS-CoV-2 antigen tests. Further research is needed to finalize time kinetics of rise and fall of various antibodies, antigen characterization and validation for clinical use.

\section{Declarations}

a) We the authors of this review titled: "Immune response in COVID-19: Sero-diagnostic evidence for clinical use and research" declare no conflict of interest.

b) The authors declare no competing interests.

c) There were no sponsors or funding sources available for this study 


\section{Contribution- SHK}

(Correspondence) Study plan, data review, manuscript writing, referencing. SKZ: Manuscript writing, data review and finalization. Both authors approved the final version of manuscript.

\section{Acknowledgements}

We acknowledge the support of Mr. Sufyan (IT Technician) in rendering the needful help where needed.

\section{References}

1. Yi Y, Lagniton PNP, Ye S, Li E, Xu RH (2020) COVID-19: what has been learned and to be learned about the novel coronavirus disease. Int J Biol Sci 16(10): 1753-1766.

2. Xiao AT, Tong YX, Zhang S (2020) False-negative of RT-PCR and prolonged nucleic acid conversion in COVID-19: Rather than recurrence.

3. Qin C, Zhou L, Hu Z, Zhang S, Yang S, et al (2020) Dysregulation of immune response in patients with COVID-19 in Wuhan, China. Clin Infect Dis 71(15): 762-768.

4. Bhattacharya N, Mukherjee H, Naskar R, Talukdar S, Das G, et al (2014) Serological diagnosis of dengue in laboratory practice in Kolkata. Indian J Med Microbiol 32(3): 277-280.

5. Cassaniti I, Novazzi F, Giardina F, Salinaro F, Sachs M, et al (2020) Performance of VivaDiag COVID-19 IgM/IgG Rapid Test is inadequate for diagnosis of COVID-19 in acute patients referring to emergency room department. J Med Virol.

6. Xie J, Ding C, Li J, Wang Y, Guo H, et al (2020) Characteristics of Patients with Coronavirus Disease (COVID-19) Confirmed using an IgM-IgG Antibody Test. J Med Virol.

7. Li Z, Yi Y, Luo X, Xiong N, Liu Y, et al (2020) Development and clinical application of a rapid IgM-IgG combined antibody test for SARS-CoV-2 infection diagnosis. J Med Virol.

8. Zhao J, Yuan Q, Wang H, Liu W, Liao X, et al (2020) Antibody responses to SARS-CoV-2 in patients of novel coronavirus disease 2019. Clin Infect Dis. 17(16): 2027-2034.

9. Guo L, Ren L, Yang S, Xiao M, Chang D, et al (2020) Profiling Early Humoral Response to Diagnose Novel Coronavirus Disease (COVID-19). Clin Infect Dis 71(15): 778-785.

10. Yongchen Z, Shen H, Wang X, Shi X, Li Y, et al (2020) Different longitudinal patterns of nucleic acid and serology testing results based on disease severity of COVID-19 patients. Emerg Microbes Infect 9(1): 833-836.

11. Gao Y, Yuan Y, Li TT, Wang XW, Li XY, et al Evaluation the auxiliary diagnosis value of antibodies assays for detection of novel coronavirus (SARS-Cov-2) causing an outbreak of pneumonia (COVID-19). J Med Virol.

12. Long Q Deng H, Chen J, Hu J, Liu B, et al (2020) Antibody responses to SARS-CoV-2 in COVID-19 patients: the perspective application of serological tests in clinical practice. Nat Med 26(6): 845-848.

13. Tan W, Lu Y, Zhang J, Wang J, Dan Y, et al (2020) Viral kinetics and antibody responses in patients with COVID-19.

14. Wise J (2020) Covid-19: Timing is critical for antibody tests, finds Cochrane review. BMJ. 369.

15. Jin Y, Wang M, Zuo Z, Fan C, Ye F, et al (2020) Diagnostic value and dynamic variance of serum antibody in coronavirus disease 2019. Int J Infect Dis. 94: 49-52.

16. Okba NMA, Müller MA, Li W, Wang C, Geurtsvan Kessel CH, et al. (2020) Severe Acute Respiratory Syndrome Coronavirus 2-Specific Antibody
Responses in Coronavirus Disease 2019 Patients. Emerg Infect Dis 26(7): 1478-1488.

17. Xiang F, Wang X, He X, Peng Z, Yang B, et al (2020) Antibody Detection and Dynamic Characteristics in Patients with COVID-19. Clin Infect Dis.

18. Castro R, Luz PM, Wakimoto MD, Veloso VG, Grinsztejn B, et al (2020) COVID-19: a meta-analysis of diagnostic test accuracy of commercial assays registered in Brazil. Braz J Infect Dis. 24(2): 180-187.

19. Infantino M, Grossi V, Lari B, Veloso VG, Grinsztejn B, et al. Diagnostic accuracy of an automated chemiluminescent immunoassay for antiSARS-CoV-2 IgM and IgG antibodies: an Italian experience. J Med Virol.

20. Yan Y, Chang L, Wang L (2020) Laboratory testing of SARS-CoV, MERSCoV, and SARS-CoV-2 (2019-nCoV): Current status, challenges, and countermeasures. Rev Med Virol 30(3): e2106.

21. Okba NMA, Müller MA, Li W, Wang C, GeurtsvanKessel CH, et al (2020) Severe Acute Respiratory Syndrome Coronavirus 2-Specific Antibody Responses in Coronavirus Disease 2019 Patients. Emerg Infect Dis. 26(7): 1478-1488.

22. Hoffman T, Nissen K, Krambrich J, Rönnberg B, Akaberi B, et al. (2020) Evaluation of a COVID-19 IgM and IgG rapid test; an efficient tool for assessment of past exposure to SARS-CoV-2. Infection Ecology \& Epidemiology 10(1): 1754538.

23. Hoffman T, Nissen K, Krambrich J, Rönnberg B, Akaberi D, Esmaeilzadeh M (2020) Evaluation of a COVID-19 IgM and IgG rapid test; an efficient tool for assessment of past exposure to SARS-CoV-2. Infection Ecology \& Epidemiology. 10(1): 1754538.

24. Liu W, Liu L, Kou G, Zheng Y, Ding Y, et al. (2020) Evaluation of Nucleocapsid and Spike Protein-based ELISAs for detecting antibodies against SARS-CoV-2. J Clin Microbiol. 58(6).

25. Zainol Rashid Z, Othman SN, Abdul Samat MN, Ali UK, Wong KK. (2020) Diagnostic performance of COVID-19 serology assays. Malays J Pathol. 42(1): $13-21$.

26. Espejo AP, Akgun Y, Al Mana AF, Tjendra Y, Millan CM, et al (2020) Review of Current Advances in Serologic Testing for COVID-19. Am J Clin Pathol.

27. Nicol T, Lefeuvre C, Serri O, Pivert A, Joubaud F, et al. (2020) Assessment of SARS-CoV-2 serological tests for the diagnosis of COVID-19 through the evaluation of three immunoassays: Two automated immunoassays (Euroimmun and Abbott) and one rapid lateral flow immunoassay (NG Biotech). J Clin Virol.

28. Padoan A, Sciacovelli L, Basso D, Negrini D, Zuin S, et al. (2020) IgA-Ab response to spike glycoprotein of SARS-CoV-2 in patients with COVID-19: A longitudinal study. Clin Chim Acta. 507:164-166.

29. Matricardi PM, Dal Negro RW, Nisini R. The first, holistic immunological model of COVID-19: implications for prevention, diagnosis, and public health measures. Pediatr Allergy Immunol. 31(5): 454-470.

30. Ma H, Zeng W, He H, Zhao D, Yang Y, et al (2020) COVID-19 diagnosis and study of serum SARS-CoV-2 specific IgA, IgM and IgG by chemiluminescence immunoanalysis. Medrxiv org.

31. Dahlke C, Heidepriem J, Kobbe R, Santer R, Koch T, et al. (2020) (IDUKE COVID-19 study group). Distinct early IgA profile may determine severity of COVID-19 symptoms: an immunological case series.

32. Lee H, Ryu JH, Park HS, Park KH, Bae H, et al. (2019) Comparison of Six Commercial Diagnostic Tests for the Detection of Dengue Virus NonStructural-1 Antigen and IgM/IgG Antibodies. Ann Lab Med. 39(6): 566-571.

33. Lau SK, Woo PC, Wong BH, Tsoi H, Woo SKG, et al. (2004) Detection of severe acute respiratory syndrome (SARS) coronavirus nucleocapsid protein in sars patients by enzyme-linked immunosorbent assay. J Clin Microbiol. 42(7): 2884-2889. 
34. The NativeAntigen Company. Why We Need Antigen and Antibody Tests for COVID-19.

35. Standard Q COVID-19 Ag Test. Clinical Effectiveness. SD Biosensor, Inc. C-BE100-TF561P61-10, Rev.00. March 9, 2020. Department of Laboratory Medicine, Seoul National University Bundang Hospital, Korea.

36. Seo G, Lee G, Kim MJ, Baek S, Choi M, et al (2020) Rapid Detection of COVID-19 Causative Virus (SARS-CoV-2) in Human Nasopharyngeal Swab Specimens Using Field-Effect Transistor-Based Biosensor. ACS Nano. 14(4): 5135-5142.

37. Mertens P, De Vos N, Martiny D, Jassoy C , Mirazimi A, et al (2020) LHUB-ULB SARS-CoV-2 Working Diagnostic Group . Development and Potential Usefulness of the COVID-19 Ag Respi-Strip Diagnostic Assay in a Pandemic Context. Front Med (Lausanne) 7: 225.
38. Blairon L, Wilmet A, Beukinga I, Tré-Hardy M (2020) Implementation of rapid SARS-CoV-2 antigenic testing in a laboratory without access to molecular methods: Experiences of a general hospital. J Clin Virol 129: 104472 .

39. Scohy A, Anantharajah A, Bodéus M, Kabamba-Mukadi B, Verroken A, et al. (2020) Low performance of rapid antigen detection test as frontline testing for COVID-19 diagnosis. J Clin Virol 129: 104455.

40. Porte L, Legarraga P, Vollrath V, Aguilera X, Munita MJ, et al (2020) Evaluation of novel antigen-based rapid detection test for the diagnosis of SARS-CoV-2 in respiratory samples. Int J Infect Dis 99: 328-333. 